\title{
A nitrogén, réz és molibdén kezelések hatása a tritikáléra
}

\author{
KÁDÁR Imre
}

MTA ATK Talajtani és Agrokémiai Intézet, Budapest

\section{Bevezetés}

Magyarországon a tritikále gyakorlatilag mindenütt megterem, és kiváló takarmányt adhat. Elterjedésével a jobb talajon termett kukorica vagy búza nagyobb része exportálható, valamint a fehérjeforrásul szolgáló szójaliszt importja mérsékelhetô. Korábbi vizsgálataink szerint savanyú homoktalajon a magtermés N-tartalma 1,4-2,5\% volt, azaz 9-16\% nyersfehérjét tartalmazott részben az évektől, döntően azonban a trágyázástól függően (KÁDÁR \& SZEMES, 1994; KÁDÁR et al., 1999). Hasonló eredményekről számol be Duna-Tisza közi meszes homokon beállított trágyázási kísérletében LÁSZTITY (1986).

Korábban LÁsZTITY (1984) összehasonlította a rozs és a tritikále szemtermésének ásványi összetételét egy NPK mütrágyázási kísérletben és megállapította, hogy a két növény makro- és mikroelem készlete érdemben nem tér el egymástól. A tritikále termése a trágyázatlan kontrollon $1,4 \mathrm{t} \cdot \mathrm{ha}^{-1}$, az NPK-trágyázott területen $3,8 \mathrm{t} \cdot \mathrm{ha}^{-1}$, míg ugyanitt a rozs 2,4 és $3,8 \mathrm{t} \cdot \mathrm{ha}^{-1}$ magtömeget adott. Részletes vizsgálati eredményeket közölt a növény szárazanyagának gyarapodásáról és tápelem tartalmának változásáról is a tenyészidő folyamán, valamint az NPK kezelések függvényében, meszes homoktalajon végzett kísérletek során (LÁsZTITY, 1987-1988).

Ami az $1 \mathrm{t}$ magtermés és a hozzá tartozó melléktermés fajlagos elemtartalmát illeti, LÁSZTITY és BICZÓK (1987-1988) az alábbi értékeket közölte, mint kísérleti átlagokat: $30 \mathrm{~kg} \mathrm{~N}, 11 \mathrm{~kg} \mathrm{P} \mathrm{O}_{5}, 24 \mathrm{~kg} \mathrm{~K} \mathrm{O}_{2}, 4 \mathrm{~kg} \mathrm{Ca}, 2 \mathrm{~kg} \mathrm{Mg}, 300 \mathrm{~g} \mathrm{Fe}, 98 \mathrm{~g} \mathrm{Mn}$, $35 \mathrm{~g} \mathrm{Zn}$ és $10 \mathrm{~g} \mathrm{Cu}$. Legnagyobb szórásokat a N-készlet mutatta, mely a meszes homok kontroll és az NPK trágyázott területeken 24 , illetve $32 \mathrm{~kg}$ volt.

A savanyú homoktalajon beállított nyírlugosi tartamkísérletünkben, a tritikále számára kedvező 1991-es évben $25-30 \mathrm{~kg} \mathrm{~N}, 10-12 \mathrm{~kg} \mathrm{P}_{2} \mathrm{O}_{5}, 18-24 \mathrm{~kg} \mathrm{~K}_{2} \mathrm{O}, 2-3$ $\mathrm{kg} \mathrm{Ca}, 2 \mathrm{~kg} \mathrm{Mg}$, 70-140 g Fe, 200-600 g Mn, 45-80 g Zn és 7-11 g Cu fajlagosok adódtak (KÁDÁR \& SZEMES, 1994).

A fenti adatokat összevetve látható, hogy míg a N, P, K és Cu fajlagosok átlagai közelállók a két eltérő termőhelyen, addig a meszes talajon nagyobb $\mathrm{Ca}$ és $\mathrm{Fe}$, illetve kisebb Mn és Zn értékek jellemzők.

A fajlagos mikroelem-tartalmakat közvetlenül nem használjuk trágyaigény becslésére a szaktanácsadás során, hiszen a mikroelemek felvehetőségét általában

Postai cím: KÁDÁR IMRE, MTA Agrártudományi Kutatóközpont Talajtani és Agrokémiai Intézet, 1022 Budapest, Herman Ottó út 15.E-mail: kadar@rissac.hu 
nem azok mennyisége a talajban, hanem egyéb talajtulajdonságok szabályozzák. A fontosabb makroelemek fajlagosai - elsősorban a N, a P és a $\mathrm{K}$ - viszont iránymutatóul szolgálhatnak.

A molibdén bár esszenciális elem, hiányát ritkán sikerül kimutatni növényben, állatban, illetve emberben, mert az élővilág rendkívül kis mennyiségben igényli. A túlsúlya jelenthet problémát. A talajban nem kötődik meg, így arid vidékeken a $\mathrm{Na}, \mathrm{B}$, Se és egyéb mobilis elemekkel együtt a feltalajban dúsul. A talaj/növény rendszer nem szüri ki. A növény hiperakkumulátorként halmozza fel a tömegárammal bejutó Mo-t. A takarmányban, illetve a legelőfüben található molibdén túlsúlya mérgezést, molibdenózist, a legelőhasmenés tünetegyüttesét okozza. A vizet áteresztő kilúgzásos talajokon nem lép fel Mo-toxicitás.

A Mo-toxicitás gyakran Cu-hiányként jelentkezik. Az optimális $\mathrm{Cu} / \mathrm{Mo}$ aránya 5-10 között van. Ha ez az arány kettő alá süllyed, fennállhat a mérgezés potenciális veszélye. Luxusfelvételkor a Mo döntően vízoldható formában van a növényben, így gyorsan felszívódik az állati gyomorban. A növényre ez a luxusfelvétel nem mérgező. Tőzeges, lápos talajon a $\mathrm{Cu}$ a szerves anyaghoz erősen kötődik, míg a Mo nem tud kimosódni. Így valódi, abszolút $\mathrm{Cu}$-hiányos és Mo-túlsúlyos növényzet fejlödik. A Mo koncentrációja akár nagyságrenddel meghaladhatja a réz koncentrációját a növényben.

A szokásos Mo-tartalom a növényekben 0,1-2 $\mathrm{mg} \cdot \mathrm{kg}^{-1} \mathrm{közötti.} \mathrm{Az} \mathrm{egészségügyi}$ maximum a takarmányban 10-20 $\mathrm{mg} \cdot \mathrm{kg}^{-1}$ (CHANEY, 1982; SAUERBECK, 1985; KLOKE et al., 1988). Humántoxikológiai szempontból viszonylag „békés” elemnek tekintik a molibdént, ivóvizekre nincs is határkoncentráció megadva.

Az 50/2001. (IV.3.) Korm. rendelet szerint mezőgazdasági felhasználás esetén a szennyvizekben $0,02 \mathrm{mg} \cdot 1^{-1}$, szennyvíziszapokban $20 \mathrm{t} \cdot \mathrm{ha}^{-1}$ a megengedett. A talaj ilyen módon $0,2 \mathrm{~kg} \cdot(\text { ha·év })^{-1}$ molibdénnel terhelhető, a szántott rétegben maximum $7 \mathrm{mg} \cdot \mathrm{kg}^{-1}$ összes Mo-tartalom eléréséig.

Megemlíthető még, hogy a Mo-toxicitás az antagonista $\mathrm{Cu}$ és $\mathrm{S}$ elemek sóinak adagolásával gyógyítható. Az állati szervekben, főként a vesében és a májban, illetve a vérben felhalmozódó Mo döntően a vizelettel ürül.

\section{Anyag és módszer}

A N x Cu kölcsönhatásokat vizsgáló kéttényezős kísérletet 1988 tavaszán állítottuk be az MTA ATK TAKI nagyhörcsöki kísérleti telepén. A kísérlet talaja löszön képződött meszes csernozjom, amely a kísérlet beállítása előtt 1988 március elején végzett talajvizsgálataink szerint mintegy 5\% karbonátot és 3\% humuszt tartalmazott a szántott rétegben.

A pH(KCl) 7,3, az AL- $\mathrm{P}_{2} \mathrm{O}_{5} 128 \mathrm{mg} \cdot \mathrm{kg}^{-1}$, az AL- $\mathrm{K}_{2} \mathrm{O} 243 \mathrm{mg} \cdot \mathrm{kg}^{-1}$, a $\mathrm{KCl}-\mathrm{Mg}$ 150-180 $\mathrm{mg} \cdot \mathrm{kg}^{-1}$. Az EDTA-Mn $127 \mathrm{mg} \cdot \mathrm{kg}^{-1}$, az EDTA-Cu 2-3 $\mathrm{mg} \cdot \mathrm{kg}^{-1}$, az EDTA-Zn 1-2 mg $\mathrm{kg}^{-1}$ értékekkel jellemezhetők. A feltalaj KCl-oldható $\mathrm{NH}_{4}-\mathrm{N}$ és $\mathrm{NO}_{3}-\mathrm{N}$ tartalma 9, illetve $12 \mathrm{mg} \cdot \mathrm{kg}^{-1}$. A BUZÁs és munkatársai (1979) által javasolt módszerek és határértékek alapján ezek az adatok a talaj jó $\mathrm{Ca}, \mathrm{Mg}, \mathrm{K}$ és $\mathrm{Mn}$, kielégítő $\mathrm{Cu}$, valamint gyenge P- és Zn-ellátottságáról tanúskodnak. 
A talajvíz szintje 13-15 m mélyen helyezkedik el, a terület aszályérzékeny. Éghajlata az Alföldéhez hasonlóan szárazságra hajló, évi átlagos középhőmérséklete $11^{\circ} \mathrm{C}$, éves átlagos csapadékösszege $576 \mathrm{~mm}$.

A kísérlet osztott parcellás (split-plot) elrendezésű $4 \mathrm{~N} \times 3 \mathrm{Cu}=12$ kezeléssel és három ismétléssel, összesen 36 parcellával. A parcellák mérete $4,9 \times 15=73,5 \mathrm{~m}^{2}$. $\mathrm{Az}$ alaptrágyázás évente $100 \mathrm{~kg} \cdot \mathrm{ha}^{-1} \mathrm{P}_{2} \mathrm{O}_{5}$ és $100 \mathrm{~kg} \cdot \mathrm{ha}^{-1} \mathrm{~K}_{2} \mathrm{O}$ adagot jelentett szuperfoszfát és kálisó formájában. A nitrogént $25 \%$-os pétisó $\left(\mathrm{Ca}-\mathrm{NH}_{4} \mathrm{NO}_{3}\right)$, a $\mathrm{Cu}$ trágyát $25,5 \%$-os $\mathrm{CuSO}_{4} \times 5 \mathrm{H}_{2} \mathrm{O}$ formában alkalmaztuk.

A PK mütrágyákat és a N felét az elővetemény lucerna törésére szórtuk ki 1987 őszén és leszántottuk, míg a $\mathrm{N}$ másik felét és a $\mathrm{CuSO}_{4}$ trágyát 1988 tavaszán, vetés előtt kevertük a talajba. Az 5. évben, 1992 tavaszán a 15 m hosszú parcellákat megfeleztük és egy $1 \mathrm{~m}$-es úttal elválasztottuk. Az osztott parcellás kísérletünk háromtényezössé vált: $4 \mathrm{~N} \times 3 \mathrm{Cu} \times 2 \mathrm{Mo}=24$ kezelés $\times 3$ ismétlés $=72$ parcella. A felezett parcellákra $48 \mathrm{~kg} \cdot \mathrm{ha}^{-1}$ molibdént szórtunk ki kora tavasszal, a $\mathrm{N}$-fejtrágyával egy időben. A Mo trágyát $\left(\mathrm{NH}_{4}\right)_{6} \mathrm{Mo}_{7} \mathrm{O}_{24} \times \mathrm{XH}_{2} \mathrm{O}$ formában adagoltuk. A N és a Mo sókat a következő napok csapadéka a talajba mosta.

A vizsgált tényezők az alábbiak:

1. tényezö (föparcellák): 2 . tényezö (alparcellák): $\mathrm{N}_{0}=0 \mathrm{~kg} \mathrm{~N} \cdot \mathrm{ha}^{-1} \cdot \mathrm{év}^{-1} \quad \mathrm{Cu}_{0}=0 \mathrm{~kg} \mathrm{Cu} \cdot \mathrm{ha}^{-1} \cdot \mathrm{é}^{-1}$

$\mathrm{N}_{1}=100 \mathrm{~kg} \mathrm{~N} \cdot \mathrm{ha}^{-1} \cdot \mathrm{év}^{-1} \quad \mathrm{Cu}_{1}=50 \mathrm{~kg} \mathrm{Cu} \cdot \mathrm{ha}^{-1} \cdot \mathrm{év}^{-1}$

$\mathrm{N}_{2}=200 \mathrm{~kg} \mathrm{~N} \cdot \mathrm{ha}^{-1} \cdot \mathrm{é}^{-1}$

$\mathrm{Cu}_{2}=100 \mathrm{~kg} \mathrm{Cu} \cdot \mathrm{ha}^{-1} \cdot \mathrm{év}^{-1}$

3. tényező (al-alparcellák):

$\mathrm{Mo}_{0}=0 \mathrm{~kg} \mathrm{Mo} \cdot \mathrm{ha}^{-1} \cdot \mathrm{é}^{-1}$

$\mathrm{Mo}_{1}=4 \mathrm{~g} \mathrm{Mo} \cdot \mathrm{ha}^{-1} \cdot \mathrm{év}^{-1}$

$\mathrm{N}_{3}=300 \mathrm{~kg} \mathrm{~N} \cdot \mathrm{ha}^{-1} \cdot \mathrm{év}^{-1}$

(1992 tavasza óta)

\section{A tartamkisérletben termesztett növények}

A kísérlet 1. évében (1988-ban) tavaszi árpa, majd 1989-ben őszi búza, 1990ben öszi árpa, 1991-ben kukorica, 1992-ben tritikále és 1993-ban burgonya volt a termesztett növény. Az N x Cu tartamkísérlet növényi sorrendje a 15 év folyamán az 1. táblázatban látható.

\section{1. táblázat}

A N x Cu tartamkísérlet növényi sorrendje 1988 és 2002 között (Mészlepedékes csernozjom vályogtalaj, Nagyhörcsök, Mezőföld)

\begin{tabular}{|c|c|c|c|c|c|}
\hline $\begin{array}{l}\text { (1) } \\
\text { Kísérlet } \\
\text { éve }\end{array}$ & $\begin{array}{c}\text { (2) } \\
\text { Növényfaj } \\
\text { (forgó) }\end{array}$ & Fajta (hibrid) & $\begin{array}{c}\text { (1) } \\
\text { Kísérlet } \\
\text { éve }\end{array}$ & $\begin{array}{l}\text { (2) } \\
\text { Növényfaj (forgó) }\end{array}$ & Fajta (hibrid) \\
\hline 1988 & $\begin{array}{l}\text { a) tavaszi } \\
\text { árpa }\end{array}$ & Opal & 1996 & i) lucerna & Szarvasi-1 \\
\hline 1989 & b) őszi búza & MV-15 & 1997 & i) lucerna & Szarvasi-1 \\
\hline 1990 & c) őszi árpa & MV-35 & 1998 & i) lucerna & Szarvasi-1 \\
\hline 1991 & d) kukorica & Pi 3732 & 1999 & i) lucerna & Szarvasi-1 \\
\hline 1992 & e) tritikále & Presto & 2000 & j) repce & Wester \\
\hline 1993 & f) burgonya & Desirée & 2001 & k) mák & Kék Duna \\
\hline 1994 & g) zab & Leanda & 2002 & 1) napraforgó & IHNK hibrid \\
\hline 1995 & h) rozs & Kisvárdai-1 & 2003 & a) tavaszi árpa & Orbit \\
\hline
\end{tabular}




\section{Mintavétel és laboratóriumi vizsgálatok}

A tritikále vetésére 1991. október 30-án került sor. Az állományt április végén (bokrosodásban) bonitáltuk fejlettségre (1-5 skálán). Ezzel egy időben a hajtás mintavételére is sor került 4-4 fm parcellánkénti földfeletti anyag begyüjtésével. Aratáskor a parcellák nettó területéről $\left(7 \times 2,1=14,7 \mathrm{~m}^{2}\right)$ kombájnolt csíkok termése került betakarításra. A parcellák nettó területéről bokrosodás végén és aratás előtt (július 21-én) 4-4 fm, azaz $0,5 \mathrm{~m}^{2}$ területröl földfeletti növénymintákat vettünk a kémiai analízis, a tömegmérés, az aratáskori szem/szalma, illetve a szem/pelyva arányának meghatározásához. Az 1000-szem súlyát 4 x 500 db mag mérésével állapítottuk meg, szintén parcellánként. A kísérletben alkalmazott agrotechnikai müveletekről és módszertani beavatkozásokról, illetve megfigyelésekről a 2. táblázat nyújt áttekintést.

Az elővetemény kukorica 1991-ben a talajt meglehetősen kiszárította. Még az 1991-es év októberében $90 \mathrm{~mm}$, novemberben $52 \mathrm{~mm}$, illetve decemberben $17 \mathrm{~mm}$ eső esett. Ezt követően 1992 januárjában nem volt csapadékesemény, míg februárban $11 \mathrm{~mm}$, márciusban $26 \mathrm{~mm}$, áprilisban $18 \mathrm{~mm}$, májusban $9 \mathrm{~mm}$ és júniusban $156 \mathrm{~mm}$ volt a csapadék. A száraz tavasz után a június első felében hullott böséges csapadékot a tritikále hasznosítani tudta.

\section{2. táblázat}

Agrotechnikai müveletek és megfigyelések a tritikále kísérletben 1992-ben (Mészlepedékes csernozjom vályogtalaj, Nagyhörcsök, Mezőföld)

\begin{tabular}{|c|c|c|}
\hline $\begin{array}{c}\text { (1) } \\
\text { Müveletek megnevezése }\end{array}$ & $\begin{array}{c}(2) \\
\text { Időpontja }\end{array}$ & $\begin{array}{c}\text { (3) } \\
\text { Módszertani megjegyzések }\end{array}$ \\
\hline Öszi mütrágyázás $(\mathrm{N}, \mathrm{P}, \mathrm{K})$ & 1991.10.28. & Parcellánként kézzel \\
\hline Szántás $(0-20 \mathrm{~cm})$ & 1991.10.28. & MTZ-50 + Lajta eke \\
\hline Gyürüshengerezés & 1991.10.28. & MTZ-50 + gyürüshenger \\
\hline Vetőágykészítés & 1991.10.30. & MTZ-50 + tárcsa és kombinátor \\
\hline Vetés és hengerezés & 1991.10.30. & MTZ-50 + Lajta vetőgép \\
\hline Hengerezés, magtakarás & 1991.10.30. & MTZ-50 + simahenger \\
\hline Kelés, állomány sorol & 1991.11.20. & Egységesen az egész kísérletben \\
\hline Tavaszi N és Mo-trágyázás & 1992.03.30. & Parcellánként kézzel \\
\hline Bonitálás állományra & 1992.04.28. & Parcellánként, 1-5 skálán \\
\hline Növénymintavétel bokrosodáskor & 1992.04.28. & Hajtás 4 fm parcellánként \\
\hline Állomány virágzik & 1992.06.01. & Egységesen az egész kísérletben \\
\hline Kísérleti bemutató & 1992.06.09. & Szakmai, országos részvétellel \\
\hline Mintakéve aratáskor & 1992.07.21. & Nettó parcellánként $4-4 \mathrm{fm}=0,5 \mathrm{~m}^{2}$ \\
\hline Kombájn aratás & 1992.07.21. & Parcellánként 7 x 2,1 = 14,7 m² \\
\hline Ezerszem számlálása & 1992.08.10. & Parcellánként 4 x 500 szem \\
\hline Mintakévék cséplése & 1992.08.17. & Parcellánkénti cséplés \\
\hline Minták örlése, analízise & 1992.09.10. & Átlagminták parcellánként \\
\hline
\end{tabular}

Megjegyzés: Presto fajta elvetve 5-7 cm mélyre, $300 \mathrm{~kg} \cdot \mathrm{ha}^{-1}$; illetve $60-70 \mathrm{db} \cdot \mathrm{fm}^{-1}$ vetömagnormával 
A tenyészidő kilenc hónapja alatt, október és június között, 379 mm csapadékkal rendelkezett az állomány. A maximális hömérséklet is mérsékelt maradt $20-25^{\circ} \mathrm{C}$ intervallumban, mely kedvezett a szemképződésnek.

A mintakévék mérése, szárítása, cséplése, őrlése a kísérleti telepen történt. A növényi anyagokat $40-50{ }^{\circ} \mathrm{C}$-on szárítottuk, majd finomra öröltük. A minták laboratóriumi elökészítése a kísérleti telepen történt. A laboratóriumi vizsgálatokat az MTA ATK Talajtani és Agrokémiai Intézetben végeztük az alább ismertetett módszerekkel:

Növényelemzés: A bemért $0,5 \mathrm{~g}$ légszáraz anyaghoz $5 \mathrm{~cm}^{3} \mathrm{cc} \cdot \mathrm{HNO}_{3}+1 \mathrm{~cm}^{3}$ cc. $\mathrm{H}_{2} \mathrm{O}_{2}$ adagolása, majd 15 perces roncsolás a mikrohullámú berendezésben. Az ásványi elemek mérése ICP-AES készüléken. A N-tartalom meghatározása: 0,5 g légszáraz anyaghoz $10 \mathrm{~cm}^{3}$ cc. $\mathrm{H}_{2} \mathrm{SO}_{4}+\mathrm{cc} . \mathrm{H}_{2} \mathrm{O}_{2}$ szükség szerint adagolva, a módosított KJELDAHL (1891) eljárással (MSZ 20135:1999).

Talajelemzés: A $\mathrm{KCl}+$ EDTA oldható Cu-tartalmat, valamint az $1 \mathrm{~mol} \cdot \mathrm{l}^{-1} \mathrm{KCl}$ kicserélhető $\mathrm{NH}_{4}-\mathrm{N}$ és $\mathrm{NO}_{3}-\mathrm{N}$ tartalmakat a MÉM NAK (1978) szerint, illetve BARANYAI és munkatársai (1987) által ismertetett eljárásokkal vizsgáltuk.

Az NH NH$_{4}$-acetát + EDTA oldható ásványi elemeket a LAKANEN és ERVIÖ (1971), a humuszt a TYURIN (1937), az ammoniumlaktát + ecetsav oldható elemeket az EGNÉR és munkatársai (1960) által ismertetett módszerekkel, az összes N-t a módosított KJELDAHL (1891) eljárással (ISO 11261:1995) határoztuk meg.

\section{Eredmények}

A 3. táblázat adatai szerint a $100 \mathrm{~kg} \cdot\left(\mathrm{ha} \cdot \mathrm{év}^{-1} \mathrm{~N}\right.$-trágyázás hatékonynak mutatkozott; a kontrollhoz viszonyítva fejlettebb állományt, nagyobb hajtástömeget, magasabb virágzáskori növényzetet eredményezett. A nitrogén-túlsúllyal mérséklődött a hajtás légszárazanyag-tartalma, azaz vízben dúsabb, élettanilag fiatalabb, aktívabb szövetek képződtek.

\section{3. táblázat}

N-trágyázás hatása a tritikále fejlődésére 1992-ben (Mészlepedékes csernozjom vályogtalaj, Nagyhörcsök, Mezöföld)

\begin{tabular}{|c|c|c|c|c|c|}
\hline$\stackrel{(1)}{\mathrm{N} \text {-szintek }}$ & $\begin{array}{l}\text { (2) } \\
\text { Bonitálás* }\end{array}$ & $\begin{array}{c}\text { (3) } \\
\text { Friss } \\
\text { hajtás }\end{array}$ & $\begin{array}{l}\text { (4) } \\
\text { Légszáraz } \\
\text { hajtás }\end{array}$ & $\begin{array}{c}\text { (5) } \\
\text { Légszáraz } \\
\text { anyag }\end{array}$ & $\begin{array}{c}(6) \\
\text { Magasság** }\end{array}$ \\
\hline $\mathrm{kg} \cdot(\mathrm{ha} \cdot \mathrm{e} \mathrm{v})^{-1}$ & április 28. & $t \cdot h a^{-1}$ & $t \cdot h a^{-1}$ & $\%$ & $\mathrm{~cm}$ \\
\hline 0 & 2,2 & 3,92 & 0,62 & 15,8 & 85 \\
\hline 100 & 4,3 & 8,26 & 1,18 & 14,3 & 92 \\
\hline 200 & 4,2 & 9,11 & 1,24 & 13,6 & 88 \\
\hline 300 & 4,2 & 9,56 & 1,30 & 13,6 & 89 \\
\hline a) Átlag & 3,7 & 7,56 & 1,08 & 14,3 & 88 \\
\hline b) $\mathrm{SzD}_{5 \%}$ & 1,0 & 1,13 & 0,16 & 0,9 & 5 \\
\hline
\end{tabular}

Megjegyzés: *Bonitálás: 1 = igen gyengén és 5 = igen jól fejlett állomány; **Virágzáskor 
4. táblázat

N-trágyázás hatása a tritikále termésére aratáskor 1992-ben (Mészlepedékes csernozjom vályogtalaj, Nagyhörcsök, Mezőföld)

\begin{tabular}{|c|c|c|c|c|c|}
\hline $\begin{array}{c}(1) \\
\text { N-szintek }\end{array}$ & $\begin{array}{c}(2) \\
\text { Ezermag } \\
\text { tömeg }\end{array}$ & $\begin{array}{c}(3) \\
\text { Szalma }\end{array}$ & $\begin{array}{c}(4) \\
\text { Pelyva }\end{array}$ & $\begin{array}{c}(5) \\
\text { Szem }\end{array}$ & $\begin{array}{c}\text { (6) } \\
\text { Együtt }\end{array}$ \\
\hline $\mathrm{kg} \cdot(\mathrm{ha} \cdot \mathrm{e} v)^{-1}$ & $\mathrm{~g}$ & \multicolumn{4}{|c|}{$\mathrm{t} \cdot \mathrm{ha}^{-1}$} \\
\hline 0 & 3,40 & 1,27 & 4,10 & 8,8 & 3,40 \\
100 & 4,55 & 1,59 & 5,72 & 11,9 & 4,55 \\
200 & 4,67 & 1,59 & 5,78 & 12,0 & 4,67 \\
300 & 4,59 & 1,52 & 5,49 & 11,6 & 4,59 \\
a) Átlag & 4,30 & 1,49 & 5,27 & 11,1 & 4,30 \\
b) SzD & 0,25 & 0,08 & 0,25 & 0,5 & 0,25 \\
\hline
\end{tabular}

A pozitív N-hatás aratás idején is kimutatható volt a szem és a szalma termésében. A 200 és $300 \mathrm{~kg} \cdot\left(\right.$ ha·év) ${ }^{-1} \mathrm{~N}$-adagok már a termést nem növelték, de terméscsökkenést sem okoztak.

A fötermés/melléktermés aránya kb. 1,1 volt. Az összes földfeletti légszáraz biomassza tömege maximálisan $12 \mathrm{t} \cdot \mathrm{ha}^{-1}$ mennyiséget ért el. A réz és a molibdén kezelések a termés alakulását nem befolyásolták (4. táblázat).

$\mathrm{Az}$ emelkedő $\mathrm{N}$-adagokkal látványosan változott egy sor elem koncentrációja a fiatal hajtásban, kimutatható a $\mathrm{N}, \mathrm{K}, \mathrm{Ca}, \mathrm{Mg}, \mathrm{S}, \mathrm{Na}, \mathrm{Ni}$ és a $\mathrm{NO}_{3}-\mathrm{N}$ akkumulációja. Ez alól kivételt csupán a Ba képez. A N-túlsúlyt, a luxusfelvételt jól mutatja a $\mathrm{NO}_{3}-\mathrm{N}$ felhalmozódása, mely csaknem hétszeresére ugrik a $300 \mathrm{~kg} \cdot(h a \cdot e ́ v)^{-1} \mathrm{~N}$-terhelésnél a kontrollhoz viszonyítva (5. táblázat).

\section{5. táblázat}

A N-szintek hatása a tritikále bokrosodáskori hajtásának elemtartalmára 1992. április 28-án (Mészlepedékes csernozjom vályogtalaj, Nagyhörcsök, Mezőföld)

\begin{tabular}{|c|c|c|c|c|c|c|c|c|c|}
\hline $\begin{array}{c}(1) \\
\text { N-szintek }\end{array}$ & $\mathrm{N}$ & $\mathrm{K}$ & $\mathrm{Ca}$ & $\mathrm{Mg}$ & $\mathrm{S}$ & $\mathrm{Na}$ & $\mathrm{Ba}$ & $\mathrm{NO}_{3}-\mathrm{N}$ & $\mathrm{Ni}$ \\
\hline${\mathrm{kg} \cdot \mathrm{ha}^{-1} \cdot \mathrm{év}^{-1}}^{\mathbf{9}} \%$ & \multicolumn{6}{|c|}{$\mathrm{mg} \cdot \mathrm{kg}^{-1}$} \\
\hline 0 & 2,28 & 2,66 & 0,59 & 0,10 & 0,22 & 60 & 7,4 & 0,4 & 0,4 \\
\hline 100 & 3,57 & 3,18 & 0,60 & 0,13 & 0,30 & 173 & 5,8 & 0,7 & 0,5 \\
\hline 200 & 4,08 & 3,64 & 0,63 & 0,15 & 0,35 & 212 & 5,7 & 2,1 & 1,0 \\
\hline 300 & 4,22 & 3,73 & 0,64 & 0,15 & 0,35 & 206 & 4,7 & 2,7 & 1,4 \\
\hline a) Átlag & 3,54 & 3,30 & 0,61 & 0,13 & 0,30 & 163 & 5,9 & 1,5 & 0,8 \\
\hline b) SzD & 0,30 & 0,33 & 0,05 & 0,02 & 0,03 & 35 & 1,0 & 0,4 & 1,0 \\
\hline
\end{tabular}

Megjegyzés: Átlagos elemtartalom: P 0,32\%, Mn $110 \mathrm{mg} \cdot \mathrm{kg}^{-1}, \mathrm{Zn} 13 \mathrm{mg} \cdot \mathrm{kg}^{-1}, \mathrm{Cu} 5 \mathrm{mg} \cdot \mathrm{kg}^{-1}$, a B $3 \mathrm{mg} \cdot \mathrm{kg}^{-1}$, Mo 0,1 $\mathrm{mg} \mathrm{kg}^{-1}$. BERGMANN (1992) szerint az őszi búza bokrosodás végi hajtásának optimális összetétele: $2,3-3,8 \% \mathrm{~N} ; 3,3-4,5 \% \mathrm{~K} ; 0,35-1,00 \% \mathrm{Ca} ; 025-0,50 \% \mathrm{P}$; $0,10-0,23 \% \mathrm{Mg} ; 30-100 \mathrm{mg} \mathrm{Mn} \cdot \mathrm{kg}^{-1}, 20-70 \mathrm{mg} \mathrm{Zn} \cdot \mathrm{kg}^{-1}, 5-10 \mathrm{mg} \cdot \mathrm{kg}^{-1} \mathrm{~B}$ és Cu, illetve $0,1-$ $0,3 \mathrm{Mo} \mathrm{mg} \cdot \mathrm{kg}^{-1}$ 
Mint ismert, a $\mathrm{NO}_{3}-\mathrm{N}$ tartaléktápanyagot jelent a növényi szövetben a fehérjeképzés számára. Kiemelkedő még a Na- és a Ni-tartalom, mely elemek mennyisége szintén több mint háromszorosára emelkedett a N-kínálattal (5. táblázat).

A N-kínálat ilyetén hatása leginkább az aratáskori szalma összetételén követhetö nyomon; igazolhatóan nőtt a $\mathrm{K}, \mathrm{N}, \mathrm{Ca}, \mathrm{S}, \mathrm{Mg}, \mathrm{P}, \mathrm{Na}, \mathrm{Mn}, \mathrm{Ba}, \mathrm{Sr}$ és B koncentrációja a szalmában (6. táblázat).

\section{6. táblázat}

$\mathrm{N}$-szintek hatása a tritikále szalma és a szem elemtartalmára 1992-ben (Mészlepedékes csernozjom vályogtalaj, Nagyhörcsök, Mezőföld)

\begin{tabular}{|c|c|c|c|c|c|c|c|c|}
\hline \multirow{3}{*}{$\begin{array}{c}(1) \\
\text { N-szintek }\end{array}$} & \multicolumn{8}{|c|}{$\begin{array}{c}(2) \\
\text { Szalma }\end{array}$} \\
\hline & $\mathrm{K}$ & $\mathrm{N}$ & $\mathrm{Ca}$ & $\mathrm{S}$ & $\mathrm{Mg}$ & $P$ & $\mathrm{Na}$ & $\mathrm{Mn}$ \\
\hline & \multicolumn{4}{|c|}{$\%$} & \multicolumn{4}{|c|}{$\mathrm{mg} \cdot \mathrm{kg}^{-1}$} \\
\hline 0 & 0,89 & 0,35 & 0,29 & 0,11 & 590 & 450 & 55 & 33 \\
\hline 100 & 1,13 & 0,38 & 0,39 & 0,16 & 760 & 540 & 150 & 36 \\
\hline 200 & 1,28 & 0,46 & 0,47 & 0,18 & 820 & 600 & 198 & 41 \\
\hline 300 & 1,26 & 0,50 & 0,51 & 0,19 & 820 & 630 & 195 & 43 \\
\hline a) Átlag & 1,14 & 0,42 & 0,42 & 0,16 & 750 & 560 & 149 & 38 \\
\hline b) $\mathrm{SzD}_{5 \%}$ & 0,09 & 0,05 & 0,05 & 0,03 & 110 & 100 & 41 & 6 \\
\hline \multirow{3}{*}{$\begin{array}{c}(1) \\
\text { N-szintek* }\end{array}$} & \multicolumn{4}{|c|}{$\begin{array}{c}\text { (2) } \\
\text { Szalma }\end{array}$} & \multicolumn{2}{|c|}{$\begin{array}{c}(3) \\
\text { Szem }\end{array}$} & \multicolumn{2}{|c|}{$\begin{array}{c}(3) \\
\text { Szem }\end{array}$} \\
\hline & $\mathrm{Ba}$ & $\mathrm{Sr}$ & B & $\mathrm{Pb}$ & $\mathrm{N}$ & S & $\mathrm{Ca}$ & $\mathrm{Mn}$ \\
\hline & \multicolumn{4}{|c|}{$\mathrm{mg} \cdot \mathrm{kg}^{-1}$} & \multicolumn{2}{|c|}{$\%$} & \multicolumn{2}{|c|}{$\mathrm{mg} \cdot \mathrm{kg}^{-1}$} \\
\hline 0 & 20 & 12 & 0,9 & 0,09 & 2,15 & 0,10 & 430 & 34 \\
\hline 100 & 24 & 16 & 1,3 & 0,11 & 3,23 & 0,11 & 470 & 36 \\
\hline 200 & 28 & 19 & 2,0 & 0,43 & 3,06 & 0,12 & 500 & 38 \\
\hline 300 & 25 & 19 & 2,0 & 0,82 & 3,38 & 0,13 & 600 & 35 \\
\hline a) Átlag & 24 & 17 & 1,6 & 0,36 & 2,95 & 0,12 & 500 & 36 \\
\hline b) $\mathrm{SzD}_{5 \%}$ & 3 & 3 & 0,6 & 0,24 & 0,39 & 0,01 & 70 & 2 \\
\hline
\end{tabular}

Megjegyzés: N-szintek, $\mathrm{kg} \cdot(\mathrm{ha} \cdot \mathrm{é})^{-1}$

Nem magyarázható azonban az Pb-tartalom ugrásszerű emelkedése. A generatív szemtermés genetikailag védettebb, míg a szalma vagy a fiatal hajtás az elemek tárolója. A szemtermésben csak négy elem, a $\mathrm{N}$, a $\mathrm{S}$, a Ca és a $\mathrm{Mn}$ mérsékelt emelkedése volt igazolható mértékủ. Amint a 6 . táblázatban látható, míg a szalmában a Ca mennyisége alapján makroelemnek minősül, a szemben mikroelemnek. Bár a $\mathrm{Cu}$ és a Mo a termések tömegét nem befolyásolta, a $\mathrm{N} \mathrm{x} \mathrm{Cu}$ és $\mathrm{N}$ x Mo kölcsönhatások az adott elem felvételében megnyilvánultak. Mind a nitrogén, mind a réz kezelések növelték a hajtás, a szalma és a szem Cu-tartalmát. A Ntrágyázás nélkül a növényi szervek rézkoncentrációja igazolhatóan nem változik a Cu-terhelés hatására (7. táblázat). 
7. táblázat

N x Cu és N x Mo hatások a tritikále Cu-, illetve Mo-tartalmára 1992-ben (Mészlepedékes csernozjom vályogtalaj, Nagyhörcsök, Mezőföld)

\begin{tabular}{|c|c|c|c|c|c|c|}
\hline \multirow{3}{*}{$\begin{array}{c}\stackrel{(1)}{\mathrm{Cu} \text {-szint }} \\
\mathrm{kg} \cdot \mathrm{ha}^{-1}\end{array}$} & & & & & \multirow{3}{*}{ Átlag } & \multirow{3}{*}{$\begin{array}{c}(4) \\
\mathrm{SzD}_{5 \%}\end{array}$} \\
\hline & 0 & 100 & 200 & 300 & & \\
\hline & \multicolumn{4}{|c|}{$\mathrm{kg} \cdot\left(\mathrm{ha} \cdot \mathrm{év}^{-1}\right.$} & & \\
\hline \multicolumn{7}{|c|}{ A. Cu-tartalom a hajtás bokrosodásakor*, $\mathrm{mg} \cdot \mathrm{kg}^{-1}$} \\
\hline 0 & 4,6 & 6,3 & 6,6 & 6,9 & 6,1 & \multirow{3}{*}{2,0} \\
\hline 50 & 5,8 & 7,2 & 8,5 & 9,3 & 7,7 & \\
\hline 100 & 5,7 & 7,8 & 9,4 & 9,8 & 8,1 & \\
\hline \multirow{3}{*}{$\begin{array}{l}\text { a) Átlag } \\
\text { b) } \mathrm{SzD}_{5 \%}\end{array}$} & 5,4 & 7,1 & 8,2 & 8,7 & 7,3 & \multirow[t]{2}{*}{1,0} \\
\hline & \multicolumn{4}{|c|}{1,7} & 0,9 & \\
\hline & \multicolumn{6}{|c|}{ B. A szalma Cu-tartalma aratáskor ${ }^{* *}, \mathrm{mg} \cdot \mathrm{kg}^{-1}$} \\
\hline 0 & 1,3 & 1,9 & 1,9 & 2,1 & 1,8 & \multirow{3}{*}{1,0} \\
\hline 50 & 1,1 & 2,1 & 2,5 & 3,0 & 2,2 & \\
\hline 100 & 1,3 & 2,2 & 3,0 & 3,2 & 2,4 & \\
\hline \multirow{3}{*}{$\begin{array}{l}\text { a) Átlag } \\
\text { b) } \operatorname{SzD}_{5 \%}\end{array}$} & 1,2 & 2,1 & 2,5 & 2,8 & 2,1 & \multirow[t]{2}{*}{0,5} \\
\hline & & & & & 0,2 & \\
\hline & \multicolumn{5}{|c|}{ C. A szem Cu-tartalma aratáskor**, $\mathrm{mg} \cdot \mathrm{kg}^{-1}$} & \multirow{6}{*}{0,7} \\
\hline 0 & 3,6 & 4,0 & 4,1 & 4,1 & 4,0 & \\
\hline 50 & 4,1 & 4,9 & 4,6 & 4,4 & 4,5 & \\
\hline 100 & 3,9 & 4,6 & 4,6 & 4,5 & 3,3 & \\
\hline a) Átlag & 3,9 & 4,5 & 4,4 & 4,4 & 4,3 & \\
\hline b) $\mathrm{SzD}_{5 \%}$ & & & & & 0,3 & \\
\hline \multirow{3}{*}{$\begin{array}{c}\text { (5) } \\
\text { Mo-szint }\end{array}$} & \multirow{2}{*}{\multicolumn{4}{|c|}{$\begin{array}{c}\text { (2) } \\
\mathrm{N} \text {-szintek }\end{array}$}} & \multirow{4}{*}{$\begin{array}{c}\text { (3) } \\
\text { Átlag }\end{array}$} & \multirow{4}{*}{$\begin{array}{c}(4) \\
\text { SzD5\% }\end{array}$} \\
\hline & & & & & & \\
\hline & 0 & 100 & 200 & 300 & & \\
\hline $\mathrm{kg} \cdot \mathrm{ha}^{-1}$ & \multicolumn{4}{|c|}{$\mathrm{kg} \cdot\left(\mathrm{ha} \cdot \mathrm{év}^{-1}\right.$} & & \\
\hline \multicolumn{7}{|c|}{ D. A szalma Mo-tartalma aratáskor ${ }^{* *}, \mathrm{mg} \cdot \mathrm{kg}^{-1}$} \\
\hline 0 & $<0,10$ & 0,10 & 0,10 & 0,11 & 0,10 & - \\
\hline 48 & 85 & 105 & 139 & 130 & 115 & 18 \\
\hline \multicolumn{7}{|c|}{ E. A szem Mo-tartalma aratáskor**, $\mathrm{mg}^{*} \mathrm{~kg}^{-1}$} \\
\hline 0 & 0,2 & 0,3 & 0,2 & 0,2 & 0,2 & 0,4 \\
\hline 48 & 12,9 & 17,1 & 19,7 & 20,1 & 17,4 & 1,3 \\
\hline
\end{tabular}

Megjegyzés: * április 28; ** július 21

A molibdén-trágyázott talajon a szalma Mo-készlete három nagyságrenddel dúsul, hiperakkumulációt jelezve. A nitrogénkínálattal a Mo-akkumuláció mintegy $50 \%$-kal nőtt. A szemtermés Mo-készlete pedig két nagyságrenddel nőtt a molibdén kezelések eredményeképpen. 
A képződött növényi termékek emberi vagy állati fogyasztásra, takarmányozásra egyaránt alkalmatlanná váltak, hiszen a nemzetközi szakirodalom általában a 10-20 $\mathrm{mg} \cdot \mathrm{kg}^{-1}$ feletti Mo-tartalmat már egészségügyi maximumot meghaladó értéknek tekinti (CHANEY, 1982; SAUERBECK 1985; KLOKE et al., 1988).

\section{8. táblázat}

A tritikále átlagos elemtartalma a kísérletben 1992-ben (Mészlepedékes csernozjom vályogtalaj, Nagyhörcsök, Mezőföld)

\begin{tabular}{|l|c|c|c|c|}
\hline \multirow{2}{*}{ Elem } & \multirow{2}{*}{$\begin{array}{c}(2) \\
\text { Mérték- } \\
\text { egység }\end{array}$} & \multicolumn{3}{|c|}{$\begin{array}{c}(3) \\
\text { Elemtartalom }\end{array}$} \\
\cline { 3 - 5 } & Hajtás & Szalma & Szem \\
\hline $\mathrm{N}$ & $\%$ & 3,54 & 0,42 & 2,95 \\
$\mathrm{~K}$ & $\%$ & 3,30 & 1,14 & 0,34 \\
$\mathrm{Ca}$ & $\%$ & 0,61 & 0,42 & 0,05 \\
$\mathrm{~S}$ & $\%$ & 0,30 & 0,16 & 0,12 \\
$\mathrm{P}$ & $\%$ & 0,32 & 0,06 & 0,39 \\
$\mathrm{Mg}$ & $\%$ & 0,13 & 0,08 & 0,12 \\
$\mathrm{Na}$ & $\mathrm{mg} \cdot \mathrm{kg}^{-1}$ & 163 & 149 & 31 \\
$\mathrm{Fe}$ & $\mathrm{mg} \cdot \mathrm{kg}^{-1}$ & 104 & 74 & 25 \\
$\mathrm{Mn}$ & $\mathrm{mg} \cdot \mathrm{kg}^{-1}$ & 110 & 38 & 36 \\
$\mathrm{Al}$ & $\mathrm{mg} \cdot \mathrm{kg}^{-1}$ & 34 & 32 & $<1$ \\
$\mathrm{Sr}$ & $\mathrm{mg} \cdot \mathrm{kg}^{-1}$ & 19 & 17 & 2 \\
$\mathrm{Zn}$ & $\mathrm{mg} \cdot \mathrm{kg}^{-1}$ & 13 & 9 & 22 \\
$\mathrm{Ba}$ & $\mathrm{mg} \cdot \mathrm{kg}^{-1}$ & 6 & 24 & $<1$ \\
$\mathrm{Cu}$ & $\mathrm{mg} \cdot \mathrm{kg}^{-1}$ & 7 & 2 & 4 \\
$\mathrm{~B}$ & $\mathrm{mg} \cdot \mathrm{kg}^{-1}$ & 3,13 & 1,57 & 0,02 \\
$\mathrm{Ni}$ & $\mathrm{mg} \cdot \mathrm{kg}^{-1}$ & 0,82 & 0,02 & 0,58 \\
$\mathrm{Cd}$ & $\mathrm{mg} \cdot \mathrm{kg}^{-1}$ & 0,49 & $<0,01$ & 0,03 \\
$\mathrm{Mo}$ & $\mathrm{mg} \cdot \mathrm{kg}^{-1}$ & 0,19 & 0,10 & 0,23 \\
\hline
\end{tabular}

Megjegyzés: A hajtás esetében átlagosan $1,08 \mathrm{t} \cdot \mathrm{ha}^{-1}, 5,79 \mathrm{t} \cdot \mathrm{ha}^{-1}$ szalmatermés (pelyvával), illetve 5,27 th ha ${ }^{-1}$ szem mennyiséggel számolva; Az As, Co, Cr, Hg, Pb, illetve a Se általában méréshatár alatti $\left(<0,1 \mathrm{mg} \cdot \mathrm{kg}^{-1}\right) ; \mathrm{A}$ Mo-tartalom a szennyezetlen talajon kiemelkedő

A tritikále átlagos elemtartalmát tekintve megállapítható, hogy a legtöbb vizsgált elem fóként a fiatal hajtásban dúsult fel a legnagyobb mennyiségben. A szemtermésben a P- és a Zn-tartalom és a szennyezetlen talajon a Mo-koncentráció kiemelkedő. Az egyéb vizsgált elemek tekintetében a szalma gazdagabb, illetve az említett fiatal hajtás a leggazdagabb. Az As, Co, Cr, $\mathrm{Hg}, \mathrm{Pb}$ és Se-tartalom minden növényi részben általában $0,1 \mathrm{mg} \cdot \mathrm{kg}^{-1}$ méréshatár körüli, vagy az alatti $(8$. táblázat).

A 9. táblázat a tritikále elemfelvételét mutatja be a kísérlet átlagában. Látható, hogy már a bokrosodás végén mért hajtás is jelentős $\mathrm{N}$ és $\mathrm{K}$ elemet akkumulált, mely az aratáskori felvétel $42 \%$-át érte el a K, illetve $23 \%$-át a $\mathrm{N}$ esetében, annak ellenére, hogy a szárazanyag tömege az aratáskorinak kevesebb, mint 10\%-a. 
9. táblázat

A tritikále átlagos elemfelvétele a kísérletben 1992-ben (Mészlepedékes csernozjom vályogtalaj, Nagyhörcsök, Mezőföld)

\begin{tabular}{|c|c|c|c|c|c|c|}
\hline \multirow[b]{2}{*}{$\begin{array}{l}(1) \\
\text { Elem }\end{array}$} & \multirow[b]{2}{*}{$\begin{array}{c}\text { (2) } \\
\text { Mérték- } \\
\text { egység }\end{array}$} & \multirow[b]{2}{*}{$\begin{array}{c}\text { (3) } \\
\text { Hajtás } \\
\text { (április 28) }\end{array}$} & \multicolumn{4}{|c|}{$\begin{array}{c}(5) \\
\text { Elemfelvétel aratáskor* }\end{array}$} \\
\hline & & & $\begin{array}{c}(6) \\
\text { Szalma } \\
+ \\
\text { pelyva } \\
\end{array}$ & $\begin{array}{l}(7) \\
\text { Szem }\end{array}$ & $\begin{array}{c}(8) \\
\text { Együtt }\end{array}$ & $\begin{array}{c}\text { (9) } \\
\text { Fajlagos } * *\end{array}$ \\
\hline $\mathrm{N}$ & $\mathrm{kg} \cdot \mathrm{ha}^{-1}$ & 40,4 & 24,3 & 152,8 & 177 & 33,6 \\
\hline $\mathrm{K}$ & $\mathrm{kg} \cdot \mathrm{ha}^{-1}$ & 35,6 & 66,0 & 17,9 & 84 & 15,9 \\
\hline $\mathrm{Ca}$ & $\mathrm{kg} \cdot \mathrm{ha}^{-1}$ & 6,6 & 24,3 & 2,6 & 27 & 5,1 \\
\hline $\mathrm{P}$ & $\mathrm{kg} \cdot \mathrm{ha}^{-1}$ & 3,4 & 3,5 & 20,6 & 24 & 4,6 \\
\hline$S$ & $\mathrm{~kg} \cdot \mathrm{ha}^{-1}$ & 3,2 & 9,3 & 6,3 & 16 & 3,0 \\
\hline $\mathrm{Mg}$ & $\mathrm{kg} \cdot \mathrm{ha}^{-1}$ & 1,4 & 4,6 & 6,3 & 11 & 2,1 \\
\hline $\mathrm{Na}$ & $\mathrm{g} \cdot \mathrm{kg}$ & 176 & 863 & 163 & 1026 & 195 \\
\hline $\mathrm{Fe}$ & $\mathrm{g} \cdot \mathrm{kg}$ & 112 & 428 & 132 & 560 & 106 \\
\hline $\mathrm{Mn}$ & $\mathrm{g} \cdot \mathrm{kg}$ & 119 & 220 & 190 & 410 & 78 \\
\hline $\mathrm{Al}$ & $\mathrm{g} \cdot \mathrm{kg}$ & 37 & 185 & $<5$ & 185 & 35 \\
\hline $\mathrm{Sr}$ & $\mathrm{g} \cdot \mathrm{kg}$ & 21 & 93 & 11 & 104 & 20 \\
\hline $\mathrm{Zn}$ & $\mathrm{g} \cdot \mathrm{kg}$ & 14 & 52 & 116 & 168 & 32 \\
\hline $\mathrm{Ba}$ & $\mathrm{g} \cdot \mathrm{kg}$ & 6 & 138 & $<5$ & 138 & 26 \\
\hline $\mathrm{Cu}$ & $\mathrm{g} \cdot \mathrm{kg}$ & 8 & 12 & 21 & 33 & 6 \\
\hline B & $\mathrm{g} \cdot \mathrm{kg}$ & 3,4 & 9,1 & 0,1 & 9,2 & 1,7 \\
\hline $\mathrm{Ni}$ & $\mathrm{g} \cdot \mathrm{kg}$ & 0,9 & 0,1 & 3,1 & 3,2 & 0,6 \\
\hline $\mathrm{Cd}$ & $\mathrm{g} \cdot \mathrm{kg}$ & 0,5 & $<0,1$ & 0,2 & 0,2 & $<0,1$ \\
\hline Mo & $\mathrm{g} \cdot \mathrm{kg}$ & 0,2 & 0,3 & 6,5 & 6,8 & 1,3 \\
\hline
\end{tabular}

Megjegyzés: * július 21; ** Az 1 t szem + a hozzátartozó melléktermés elemtartalma; A hajtás $1,08 \mathrm{t} \cdot \mathrm{ha}^{-1}$, a pelyvás szalma $5,79 \mathrm{t} \cdot \mathrm{ha}^{-1}$, illetve a szem $5,27 \mathrm{t} \cdot \mathrm{ha}^{-1}$ átlagterméssel számolva; $\mathrm{Az} \mathrm{As}, \mathrm{Co}, \mathrm{Cr}, \mathrm{Hg}, \mathrm{Pb}$, Se általában $<1 \mathrm{~g} \cdot \mathrm{ha}^{-1}$, méréshatár alatti

A fiatal hajtás erőteljesen halmozta fel a tápelemeket a későbbi szárbaszökés/megnyúlás számára. Másrészről az elöregedő növényzet sok tápelemet veszített a lehulló levélzettel, illetve a K kimosódásával a levelekből. Ez utóbbira magyarázattal szolgálhat, hogy a $\mathrm{K}$ nem szerkezeti elem, így nem védett a kilúgzástól. A $11 \mathrm{t} \cdot \mathrm{ha}^{-1}$ légszáraz földfeletti biomasszába $177 \mathrm{~kg} \mathrm{~N}, 24 \mathrm{~kg} \mathrm{P}, 84 \mathrm{~kg}$ $\mathrm{K}$, illetve $27 \mathrm{~kg} \mathrm{Ca}, 16 \mathrm{~kg} \mathrm{~S}$ és $11 \mathrm{~kg} \mathrm{Mg}$ épült be. A fajlagos, azaz az $1 \mathrm{t}$ szem + a hozzátartozó melléktermés úgynevezett fajlagos elemtartalma kereken $34 \mathrm{~kg} \mathrm{~N}$, $19 \mathrm{~kg} \mathrm{~K}_{2} \mathrm{O}, 10-11 \mathrm{~kg} \mathrm{P}_{2} \mathrm{O}_{5}, 7 \mathrm{~kg} \mathrm{CaO}, 3-4 \mathrm{~kg} \mathrm{MgO}$ volt.

Adataink felhasználhatók a tritikále tervezett termése elemszükségletének számításakor a szaktanácsadásban. Megemlíthető, hogy ebben a kísérletben a fajlagos N-, Ca- és Mg-tartalom emelkedett. Ez logikailag a nitrogén kezeléseknek, illetve a meszes talajú termőhelynek tulajdonítható. 


\section{Összefoglalás}

1992-ben mészlepedékes csernozjom vályogtalajon beállított szabadföldi kísérletben vizsgáltuk a nitrogén, réz és molibén elemek közötti kölcsönhatásokat tritikáléval. A termőhely talaja a szántott rétegben 3\% humuszt, 5\% körüli karbonátot és $20 \%$ körüli agyagot tartalmazott. A talajelemzések alapján a terület jó Ca-, Mg-, K- és Mn-, kielégítő Cu-, valamint gyenge-közepes P- és Zn-ellátottságú volt. A talajvíz 13-15 m mélyen található, a terület aszályérzékeny. A tenyészidő kilenc hónapja alatt azonban $379 \mathrm{~mm}$ eső hullott, közepes csapadékellátottságot biztosítva a tritikálénak. A kísérletet $4 \mathrm{~N} \times 3 \mathrm{Cu}=12$ kezelés $\times 3$ ismétlés $=36$ parcellával állítottuk be osztott parcellás (split-plot) elrendezéssel. A N-trágyázás $0,100,200$, $300 \mathrm{~kg} \cdot \mathrm{ha}^{-1}$, a Cu-trágyázás 0,50 és $100 \mathrm{~kg} \cdot \mathrm{ha}^{-1}$ adagokat jelentett $\mathrm{Ca}-\mathrm{NH}_{4} \mathrm{NO}_{3}$, illetve $\mathrm{CuSO}_{4}$ formájában. A kísérlet ötödik évében a $15 \mathrm{~m}$ hosszú parcellákat megfeleztük és 1 m-es úttal elválasztottuk. A kísérlet így sávos split-plot elrendezésủvé vált 72 parcellával $(4 \mathrm{~N} \times 3 \mathrm{Cu} \times 2 \mathrm{Mo}=24$ kezelés $\mathrm{x} 3$ ismétlés $)$. A $48 \mathrm{~kg} \cdot$ ha $^{-1}$ molibdént $\left(\mathrm{NH}_{4}\right)_{6} \mathrm{Mo}_{7} \mathrm{O}_{24} \times 4 \mathrm{H}_{2} \mathrm{O}$ formában alkalmaztuk.

A vizsgálat fontosabb eredményei az alábbiakban foglalhatóak össze.:

- A $100 \mathrm{~kg} \cdot(h a \cdot e ́ v)^{-1} \mathrm{~N}$-adagok a szemtermést $4,1 \mathrm{t} \cdot \mathrm{ha}^{-1}$-ról 5,7 $\mathrm{t} \cdot \mathrm{ha}^{-1}$-ra növelték, míg az ennél nagyobb adagú $\mathrm{N}$-, $\mathrm{Cu}$ - és a Mo-trágyázás is hatástalan maradt.

- Levéldiagnosztikai szempontból a BERGMANN (1992) által az őszi búzára javasolt optimális elemtartalom értékek $(2,3-3,8 \% \mathrm{~N}, 3,3-4,5 \% \mathrm{~K}, 0,35-1,00 \% \mathrm{Ca}$, $0,25-0,50 \% \mathrm{P}$, illetve $0,10-0,23 \% \mathrm{Mg}$ ) megfelelő alapot jelenthetnek a tritikále tápláltsági állapotának megítéléséhez, a bokrosodásvégi hajtás összetétele alapján.

- A bőséges nitrogénkínálattal látványosan emelkedett a betakarításkori szalma $\mathrm{N}$, $\mathrm{K}, \mathrm{Ca}, \mathrm{Mg}, \mathrm{S}, \mathrm{P}, \mathrm{Na}, \mathrm{Mn}, \mathrm{Ba}, \mathrm{Sr}, \mathrm{B}$ és Pb koncentrációja. A szemtermés esetében a $\mathrm{N}, \mathrm{S}, \mathrm{Ca}$ és Mn beépülését a $\mathrm{N}$-trágyázás igazolhatóan serkentette.

- A N x Cu kezelések nyomán megkétszerezödött a hajtás és a szalma N-készlete. A Mo-trágyázott talajon a szalmában három, a szemben két nagyságrenddel nőtt meg a Mo-koncentráció. A N-kínálattal a beépült Mo mennyisége további 50\%-kal emelkedett.

- A $11 \mathrm{t} \cdot \mathrm{ha}^{-1}$ légszáraz földfeletti biomasszába kereken $177 \mathrm{~kg} \mathrm{~N}, 84 \mathrm{~kg} \mathrm{~K}, 27 \mathrm{~kg}$ $\mathrm{Ca}, 24 \mathrm{~kg} \mathrm{P}, 16 \mathrm{~kg} \mathrm{~S}$ és $11 \mathrm{~kg} \mathrm{Mg}$ épült be. Az $1 \mathrm{t}$ szem + a hozzátartozó melléktermés úgynevezett fajlagos elemtartalma átlagosan az alábbiak szerint alakult.: $34 \mathrm{~kg} \mathrm{~N}, 19 \mathrm{~kg} \mathrm{~K}_{2} \mathrm{O}, 10-11 \mathrm{~kg} \mathrm{P}_{2} \mathrm{O}_{5}, 7 \mathrm{~kg} \mathrm{CaO}, 3-4 \mathrm{~kg} \mathrm{MgO}$.

Adataink orientálhatják a szaktanácsadást a tervezett tritikále termés elemszükségletének számításakor.

Kulcsszavak: NxCuxMo kölcsönhatások, szabadföldi kísérlet, tritikále, csernozjom talaj

\section{Irodalom}

BARANYAi F., FeKeTE A. \& KovÁCS I., 1987. A magyarországi talaj tápanyagvizsgálatok eredményei. Mezőgazdasági Kiadó. Budapest. 
BergmanN, W., 1992. Nutritional Disorders of Plants. G. Fischer Verlag. Jena, Stuttgart. New York.

BUZÁs I. et al. (Szerk.), 1979. Mütrágyázási irányelvek és üzemi számítási módszer. MÉM Növényvédelmi és Agrokémiai Központ. Budapest.

ChANEY, R. L., 1982. Fate of toxic substances in sludge applies to cropland. In: Proc. Int. Symp. "Land Application of Sewage Sludge". (Ed.: CANALI et al.) 259-324). Tokyo. Japan.

EgNÉR, H., RIEHM, H. \& DOMINGO, W. R., 1960. Untersuchungen über die chemische Bodenanalyse als Grundlage für die Beurteilung des Nährstoffzustandes der Böden. II. K-Lantbr. Högsk. Ann. 26. 199-215.

KÁDÁR I. \& KASTORI R., 2006. Mikroelem-terhelés hatása a tritikále termésére és elemfelvételére karbonátos csernozjom talajon. Agrokémia és Talajtan. 55. (2) 449 460.

KÁDÁR I. \& SzEMES I., 1994. A nyírlugosi tartamkísérlet 30 éve. MTA Talajtani és Agrokémiai Kutató Intézete. Budapest.

KÁDÁR I., NÉMETH T. \& SZEMES I., 1999. Tritikále trágyareakciója a nyírlugosi tartamkísérletben. Növénytermelés. 48. 647-661.

KJELDAHL, J., 1891. Neue Methode zur Bestimmung des Stickstoffs in organischen Körpern. Zeitschrift für Analytische Chemie. 22. 366-382.

KLOKE et al., 1988. Das Drei-Bereiche-System für die Beurteilung von Böden mit Schadstoffbelastung. VDLUFA Schriftenreihe 28/2. Kongressband 1117-1127. VDLUFA-Verlag. Darmstadt.

LAKANEN, E. \& ERVIÖ, R., 1971. A comparison of eight extractants for the determination of plant available microelements in soils. Acta Agralia Fennica. 123. 223-232.

LÁSZTITY B., 1984. Az NPK-mütrágyázás hatása az őszi rozs és a tritikále szemtermésének néhány beltartalmi jellemzőjére. Agrokémia és Talajtan. 33. 391-402.

LÁsZTITY B., 1986. Néhány elem koncentrációjának változása az őszi rozsban és tritikáléban a tenyészidő folyamán. Agrokéma és Talajtan. 35. 85-94.

LÁSZTITY B., 1987-1988. A mütrágyázás hatása a tritikále szárazanyag felhalmozására és tápelemtartalmára. Agrokémia és Talajtan. 36-37. 191-208.

LÁsZTiTY B. \& BICZÓK GY., 1987-1988. A mütrágyázás hatása a tritikále tápelemfelvételének dinamikájára. Agrokémia és Talajtan. 36-37. 177-190.

MÉM NAK 1978. A TVG tápanyagvizsgáló laboratórium módszerfüzete. MÉM Növényvédelmi és Agrokémiai Központ. Budapest.

SAUERBECK, D., 1985. Funktionen, Güte und Belastbarkeit des Bodens aus agriculturchemischer Sicht. Materialien zur Umweltforschung. Kohlhammer Verlag. Stuttgart.

TYURIN, I. V., 1937. Organicseszkoe vesesesztvo pocsvü. Szel’hozgiz. Moszkva.

Érkezett: 2015. augusztus 28. 


\title{
Effect of nitrogen, copper and molybdenum treatments on triticale
}

\author{
I. KÁDÁR \\ Institute for Soil Science and Agricultural Chemistry of the \\ Hungarian Academy of Sciences, Budapest
}

\begin{abstract}
Summary
Interactions between the elements $\mathrm{N}, \mathrm{Cu}$ and $\mathrm{Mo}$ were analysed in triticale in 1992 in field experiments set up on chernozem loam soil with lime deposits. The ploughed layer of the soil contained 3\% humus, around $5 \% \mathrm{CaCO}_{3}$ and around $20 \%$ clay. Soil analysis showed that the area was well supplied with $\mathrm{Ca}, \mathrm{Mg}, \mathrm{K}$ and $\mathrm{Mn}$ had satisfactory $\mathrm{Cu}$ content, but was only poorly or moderately supplied with $\mathrm{P}$ and $\mathrm{Zn}$. The groundwater depth was $13-15 \mathrm{~m}$ and the area was prone to drought. The experiment was originally set up in a split-plot design with $4 \mathrm{~N} \times 3 \mathrm{Cu}=12$ treatments in three replications, giving a total of 36 plots. The $\mathrm{N}$ rates, applied as calcium ammonium nitrate, were $0,100,200$ and $300 \mathrm{~kg} \cdot \mathrm{ha}^{-1}$ and the $\mathrm{Cu}$ rates, in the form of $\mathrm{CuSO}_{4}$, were 0,50 and $100 \mathrm{~kg} \cdot \mathrm{ha}^{-1}$. In the $5^{\text {th }}$ year of the experiment the $15 \mathrm{~m}$ plots were divided and the two half-plots were separated by a $1 \mathrm{~m}$ path. The experiment thus became a strip-splitplot design, consisting of $4 \mathrm{~N} \times 3 \mathrm{Cu} \times 2 \mathrm{Mo}=24$ treatments in three replications, giving a total of 72 plots. The $48 \mathrm{~kg} \cdot \mathrm{ha}^{-1}$ Mo was applied in the form of $\left(\mathrm{NH}_{4}\right)_{6} \mathrm{Mo}_{7} \mathrm{O}_{24} \times 4 \mathrm{H}_{2} \mathrm{O}$. The main results were as follows:

- During the 9-month growing season there was $379 \mathrm{~mm}$ rain, representing moderate rainfall supplies for triticale. An annual $\mathrm{N}$ rate of $100 \mathrm{~kg} \cdot \mathrm{ha}^{-1}$ increased the grain yield from $4.1 \mathrm{t} \cdot \mathrm{ha}^{-1}$ to $5.7 \mathrm{t} \cdot \mathrm{ha}^{-1}$, but neither higher $\mathrm{N}$ rates nor $\mathrm{Cu}$ or Mo fertilisation had any further effect.

- For the purposes of leaf analysis, the optimum element contents recommended by BERGMANN (1992) for winter wheat could be suitable for estimating the nutritional status of triticale, based on the composition of the shoots at the end of tillering: 2.3$3.8 \% \mathrm{~N}, 3.3-4.5 \% \mathrm{~K}, 0.35-1.00 \% \mathrm{Ca}, 0.25-0.50 \% \mathrm{P}$ and $0.10-0.23 \% \mathrm{Mg}$.

- Plentiful $\mathrm{N}$ supplies led to a steep rise in the concentration of the elements $\mathrm{N}, \mathrm{K}, \mathrm{Ca}$, $\mathrm{Mg}, \mathrm{S}, \mathrm{P}, \mathrm{Na}, \mathrm{Mn}, \mathrm{Ba}, \mathrm{Sr}, \mathrm{B}$ and $\mathrm{Pb}$ in the straw at harvest. In the case of the grain yield, the incorporation of $\mathrm{N}, \mathrm{S}, \mathrm{Ca}$ and $\mathrm{Mn}$ was significantly enhanced by $\mathrm{N}$ fertilisation.

- In response to $\mathrm{N} \times \mathrm{Cu}$ treatments the $\mathrm{N}$ content of the shoots and straw was doubled. On Mo-fertilised soil the Mo concentration increased by three orders of magnitude in the straw and two in the grain. As the $\mathrm{N}$ rate increased the quantity of Mo incorporated rose by a further $50 \%$.

- Around $177 \mathrm{~kg} \mathrm{~N}, 84 \mathrm{~kg} \mathrm{~K}, 27 \mathrm{~kg} \mathrm{Ca}, 24 \mathrm{~kg} \mathrm{P}, 16 \mathrm{~kg} \mathrm{~S}$ and $11 \mathrm{~kg} \mathrm{Mg}$ was incorporated into the $11 \mathrm{t} \cdot \mathrm{ha}^{-1}$ air-dry aboveground biomass. The specific nutrient content associated with $1 \mathrm{t}$ grain + associated by-products averaged $34 \mathrm{~kg} \mathrm{~N}, 19 \mathrm{~kg} \mathrm{~K}_{2} \mathrm{O}, 10-11 \mathrm{~kg}$ $\mathrm{P}_{2} \mathrm{O}_{5}, 7 \mathrm{~kg} \mathrm{CaO}$ and 3-4 kg MgO. These data could serve as guidelines for fertilisation advisory services in calculating the nutrient requirements of the planned triticale yield.

Table 1. Crop sequence in the long-term $\mathrm{N} \times \mathrm{Cu}$ experiment between 1988 and 2002 (Chernozem loam soil with lime deposits, Nagyhörcsök, Mezöföld). (1) Year. (2) Crop species (rotation). (3) Cultivar/hybrid. a) Spring barley; (b) Winter wheat; c) Winter
\end{abstract}


barley; d) Maize; e) Triticale; f) Potato; g) Oats; h) Rye; i) Alfalfa; j) Rape; k) Poppy; 1) Sunflower.

Table 2. Technological operations and observations in the triticale experiment in 1992 (Chernozem loam soil with lime deposits, Nagyhörcsök, Mezőföld). (1) Technological operations. (2) Date. (3) Other comments. Remarks: The cultivar Presto was sown at a depth of $5-7 \mathrm{~cm}$ with a seed norm of $300 \mathrm{~kg} \cdot \mathrm{ha}^{-1}$, i.e. $60-70 \mathrm{seeds} \cdot \mathrm{m}^{-1}$.

Table 3. Effect of $\mathrm{N}$ fertilisation on the development of triticale in 1992 (Chernozem

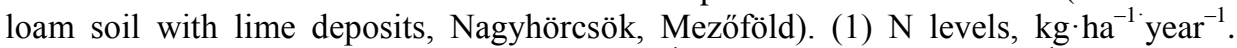
(2) Scoring on Apr. 28. (3) Fresh shoots, $t \cdot h^{-1}$. (4) Air-dry shoots, $t \cdot h a^{-1}$. (5) Air-dry matter, \%. (6) Height, cm. a) Mean; b) LSD $_{5 \%}$. Note: *Scoring: $1=$ very poorly developed, $5=$ very well developed stand. $* *$ At flowering.

Table 4. Effect of $\mathrm{N}$ fertilisation on the yield of triticale at harvest in 1992 (Chernozem loam soil with lime deposits, Nagyhörcsök, Mezöföld). (1) N levels, $\mathrm{kg} \cdot(\text { ha } \cdot \text { year })^{-1}$. (2) Thousand-kernel weight, g. (3) Straw, $\mathrm{t} \cdot \mathrm{ha}^{-1}$. (4) Husks, $\mathrm{t} \cdot \mathrm{ha}^{-1}$. (5) Grain, $t \cdot h a^{-1}$. (6) Together, $t \cdot h a^{-1}$. a) Mean; b) LSD $5 \%$.

Table 5. Effect of $\mathrm{N}$ levels on the element contents of triticale shoots at tillering on 28 Apr. 1992 (Chernozem loam soil with lime deposits, Nagyhörcsök, Mezőföld). (1) N rate, $\mathrm{kg} \cdot(\text { ha } \cdot \text { year })^{-1}$. a) Mean; b) LSD $5 \%$. Remarks: The following mean values were recorded for other elements: P $0.32 \%, \mathrm{Mn} 110 \mathrm{mg} \cdot \mathrm{kg}^{-1}, \mathrm{Zn} 13 \mathrm{mg} \cdot \mathrm{kg}^{-1}, \mathrm{Cu} 5 \mathrm{mg} \cdot \mathrm{kg}^{-1}$, B $3 \mathrm{mg} \cdot \mathrm{kg}^{-1}$, Mo $0.1 \mathrm{mg} \cdot \mathrm{kg}^{-1}$. According to BERGMANN (1992) winter wheat has the following optimum composition at the end of tillering: $2.3-3.8 \% \mathrm{~N}, 3.3-4.5 \% \mathrm{~K}, 0.35-$ $1.00 \mathrm{Ca}, 0.25-0.50 \% \mathrm{P}, 0.10-0.23 \% \mathrm{Mg}, 30-100 \mathrm{mg} \cdot \mathrm{kg}^{-1} \mathrm{Mn}, 20-70 \mathrm{mg} \cdot \mathrm{kg}^{-1} \mathrm{Zn}, 5-$ $10 \mathrm{mg} \cdot \mathrm{kg}^{-1} \mathrm{~B}$ and $\mathrm{Cu}, 0.1-0.3 \mathrm{mg} \cdot \mathrm{kg}^{-1} \mathrm{Mo}$.

Table 6. Effect of $\mathrm{N}$ levels on the element contents of triticale straw and grain in 1992 (Chernozem loam soil with lime deposits, Nagyhörcsök, Mezőföld). (1) N levels, $\mathrm{kg} \cdot(\text { ha } \cdot \text { year })^{-1}$. (2) Straw. (3) Grain. a) Mean; b) LSD $5 \%$.

Table 7. $\mathrm{N} \times \mathrm{Cu}$ effects on the $\mathrm{Cu}$ content and $\mathrm{N} \times$ Mo effects on the Mo content of triticale in 1992 (Chernozem loam soil with lime deposits, Nagyhörcsök, Mezőföld). (1) $\mathrm{Cu}$ level, $\mathrm{kg} \cdot \mathrm{ha}^{-1}$. (2) $\mathrm{N}$ levels, $\mathrm{kg} \cdot\left(\right.$ ha $\cdot$ year) ${ }^{-1}$. (3) Mean. (4) $\mathrm{LSD}_{5 \%}$. (5) Mo level, $\mathrm{kg} \cdot \mathrm{ha}^{-1}$. a) Mean; b) $\mathrm{LSD}_{5 \%}$. A) Cu content of shoots at tillering. B) Cu content of straw at harvest. C) $\mathrm{Cu}$ content of grain at harvest. D) Mo content of straw at harvest. E) Mo content of grain at harvest. Note: * on $21 \mathrm{Jul} .{ }^{* *}$ on $28 \mathrm{Apr}$.

Table 8. Element contents of triticale, averaged over the experiment in 1992 (Chernozem loam soil with lime deposits, Nagyhörcsök, Mezőföld). (1) Element. (2) Units. (3) Element content. (4) Shoots. (5) Straw. (6) Grain. Remarks: Mean yields of 1.08 $\mathrm{t} \cdot \mathrm{ha}^{-1}$ shoots, $5.79 \mathrm{t} \cdot \mathrm{ha}^{-1}$ husks and $5.27 \mathrm{t} \cdot \mathrm{ha}^{-1}$ grain were used in the calculations; Values of $\mathrm{As}, \mathrm{Co}, \mathrm{Cr}, \mathrm{Hg}, \mathrm{Pb}$ and $\mathrm{Se}$ were generally below the $0.1 \mathrm{mg} \cdot \mathrm{kg}^{-1}$ detection level.

Table 9. Mean element uptake of triticale in the experiment in 1992 (Chernozem loam soil with lime deposits, Nagyhörcsök, Mezöföld). (1) Element. (2) Units. (3) Shoots on Apr. 28. (4) Element uptake at harvest on 21 Jul. (5) Straw + husks. (6) Grain. (7) Together. (8) Specific. Remarks: * on 21 jul.; ** Element content of $1 \mathrm{t}$ grain + associated by-products; Mean yields of $1.08 \mathrm{t} \cdot \mathrm{ha}^{-1}$ shoots, $5.79 \mathrm{t} \cdot \mathrm{ha}^{-1}$ husks and $5.27 \mathrm{t} \cdot \mathrm{ha}^{-1}$ grain were used in the calculations. Values of $\mathrm{As}, \mathrm{Co}, \mathrm{Cr}, \mathrm{Hg}, \mathrm{Pb}$ and $\mathrm{Se}$ were generally below the $1 \mathrm{~g} \cdot \mathrm{ha}^{-1}$ detection level. 